\title{
ELECTRONIC GOVERNMENT POLICIES IN BRAZIL: CONTEXT, ICT MANAGEMENT AND OUTCOMES
}

\author{
POLÍTICAS DE GOVERNO ELETRÔNICO NO BRASIL: CONTEXTO, GESTÃO DE TIC E RESULTADOS \\ POLITICAS DE GOBIERNO ELECTRÓNICO EN BRASIL: CONTEXTO, GESTIÓN DE TIC Y RESULTADOS
}

\begin{abstract}
The State Reform processes combined with the emergence and use of Information and Communication Technology (ICT) originated electronic government policies and initiatives in Brazil. This paper dwells on Brazilian e-government by investigating the institutional design it assumed in the state's public sphere, and how it contributed to outcomes related to e-gov possibilities. The analyses were carried out under an interpretativist perspective by making use of Institutional Theory. From the analyses of interviews with relevant actors in the public sphere, such as state secretaries and presidents of public ICT companies, conclusions point towards low institutionalization of e-gov policies. The institutional design of Brazilian e-gov limits the use of ICT to provide integrated public services, to amplify participation and transparency, and to improve public policies management.
\end{abstract}

KEYWORDS E-gov, ICT Management, State Reform, public administration, institutional theory.

Marconi Martins de Laia marconi.laia@fjp.mg.gov.br

Professor at Escola de Governo, Fundação João Pinheiro - Belo Horizonte - MG, Brazil

Maria Alexandra Viegas Cortez da Cunha alexandra.cunha@pucpr.br

Professor at Centro de Ciências Sociais Aplicadas, Escola de Negócios, Pontifícia Universidade Católica do Paraná - Curitiba - PR, Brazil

Antonio Roberto Ramos Nogueira nogueira@coppead.ufrj.br

Professor at Instituto de Pós-Graduação e Pesquisa em Administração, Universidade Federal do Rio de Janeiro - Rio de Janeiro - RJ, Brazil

José Afonso Mazzon jamazzon@usp.br

Professor at Faculdade de Economia, Administração e Contabilidade, Universidade de São Paulo - São Paulo - SP, Brazil

Submitted 31.03.2010. Approved 30.11.2010

Evaluated in a double blind review

Scientific Editor: Eduardo Diniz, Marlei Pozzebon and Nicolau Reinhard

RESUMO Os processos de Reforma do Estado combinados com a emergência e uso de Tecnologia da Informação e Comunicação (TIC) deram origem, no Brasil, a políticas e ações de governo eletrônico. Este artigo debruça-se sobre o e-governo brasileiro, investigando o desenho institucional que ele assumiu na esfera estadual do país e como contribui para os resultados associados às possibilidades do e-gov. Numa perspectiva interpretativista, utilizou-se a Teoria Institucional como lente teórica no exame do campo. A partir da análise de entrevistas feitas a atores relevantes na esfera dos estados brasileiros, tais como secretários de estado e presidentes de empresas públicas de informática, as conclusões apontam para a baixa institucionalização das políticas de e-governo. O desenho institucional do governo eletrônico brasileiro limita a utilização das TIC na prestação de serviços públicos integrados, na ampliação de participação e transparência, e no aprimoramento de políticas públicas.

PALAVRAS-CHAVE Governo eletrônico, gestão de TIC, reforma do estado, administração pública, teoria institucional.

RESUMEN Los procesos de Reforma del Estado combinados con la emergencia y uso de Tecnologías de la Información y Comunicación (TIC) originaron, en Brasil, políticas y acciones de gobierno electrónico. Este artículo analiza el e-gobierno brasileño, investigando el modelo institucional que este asumió en la esfera estatal del país y cómo contribuye a los resultados asociados a las posibilidades del e-gob. En una perspectiva interpretativista, utilizó la Teoría Institucional como lente teórico en el examen de campo. A partir del análisis de entrevistas hechas a actores relevantes en la esfera de los estados brasileños, tales como secretarios de estado y presidentes de empresas públicas de informática, las conclusiones señalan la baja institucionalización de las políticas de e-gobierno. El modelo institucional del gobierno electrónico brasileño limita la utilización de las TIC en la prestación de servicios públicos integrados, en la ampliación de la participación y transparencia, y en el mejoramiento de las políticas públicas.

PALABRAS CLAVE Gobierno electrónico, gestión de TIC, reforma del estado, administración pública, teoría institucional. 


\section{INTRODUCTION}

The State Reform processes in the 1990s combined with the emergence and use of Information and Communication Technology (ICT) originated e-government policies and initiatives in Brazil. This paper assesses how the results of e-gov in the states of the federation are affected by the institutional design of e-gov policies.

The term e-gov refers normally to the use of ICT to provide services to the citizen, to the review and integration of processes, to improve the efficiency and efficacy of public administration, and to the creation of mechanisms of digital relations with the citizen. Although e-gov represents a scenario of possibilities for public management, a great part of theoretical and practical discussions on the benefits and potentialities of e-gov are based on a logic of will that keeps a certain technological imperative. What we notice as it is performed is that, in various situations, the effects on the use of ICT are complex and generate unpredictable results. Thus, we believe the study of the implementation of technology, including e-gov, should not restrict its technical components. For instance: one can seek understanding of institutional factors affecting technological management processes (as in this paper, for instance). The institutions give shape to the process of ICT use and end up catalyzing or moderating the implementation of e-gov. This premise guided the choice of institutionalism in its rational choice line, as a conceptual model for our investigation. The research question is: How is the institutionalization of Brazilian e-gov? Our aim is to understand the institutional design of e-gov and ICT in our state governments and how these arrangements affect the gains associated with e-gov.

To observe e-gov under an institutionalist scope has the potential of helping understand the institutional arrangement e-gov assumed and the influence of this design in the use and results of e-gov initiatives. In the past few years, several studies examined innovation, development and implementation of ICT from an institutional perspective (MIGNERAT and RIVARD, 2005; FOUNTAIN, 2005; AVGEROU, 2000). Yet, in the context of ICT in government, especially in the largest country in Latin America, these studies are in a very small number. We believe this is a contribution for that work, since approaches such as institutionalism, unusual in the field of Information Systems in Brazil, make it possible to create a solid framework for the studies of governmental ICT policies. From an empirical point of view, this research contributed for that practice, pointing out the arrangements by means of which e-gov has been implemented in Brazilian states, clarifying the challenges for the creation of a state agenda. One of the most important consequences in the process of decentralization and democratization of political power in Brazil (from the 1980s) was the growth of the importance of subnational governments, be them state or city ones. However, academic literature on public management policies for state governments is still scarce (ABRUCIO, 2004). This is another contribution we believe we are giving to conclude this research: a deep study on ICT usage policies in the state sphere.

\section{STATE REFORM AND THE USE OF ICT IN BRAZILIAN GOVERNMENTS}

In the 1970s, mostly after the oil shock in 1973, the period Hobsbawm (1995) called "Fordist Golden Age" started showing signs of collapse. A crisis was beginning in three fundamental dimensions: economical, social and of the State apparatus.

Given the crisis context, the State Reform projects were prioritized. For public administration, some lines of action became compulsory, such as: expense reduction, State apparatus efficiency increase, a need for greater agility and flexibility of the governmental apparatus to respond to external environment demands, more unstable and dynamic (BRASIL, 1995). Thatcher and Reagan governments represented a source of a new agenda internationally called "New Public Management" (NPM) which influenced the renovation movements in the 1990s in many countries.

Abrucio (1997) traces some marks of development in the processes of State Reform. For that author, they started as pure managing. They focused on the most urgent needs of changes in nations in the 1970s and 1980s - resources were scarce. Seeking to solve this, governments started adopting budget planning and cost control. A second tendency of State Reform movements, after managing, is consumerism. Attention was then focused on clients/consumers and included the administration patterns from private organizations applied to public ones. Despite their development, renovation movements started being criticized for their excessive inclusion of private administration in public administration agenda. As Mintzberg (1996) points out, citizens have rights that differ from the goods, products and services clients purchase. Therefore, certain British authors started discussing Public Service Orientation (PSO) aiming to introduce their accountability concepts - transparency, political participation, and equity (HEEKS, 1998) - in the State Reform agenda. 
The processes of State Reform are seen as a condition to enhance governance in public management, which is "the capacity of the State to efficiently and effectively transform the decisions they make into reality" (BRESSER PEREIRA, 1998, p. 109). Through governance, the State "seeks to deepen the democratic mechanisms of rendering the government responsible and transparent" (BRESSER PEREIRA, 1998, p. 109). Thus, the State Reform movements brought up the discussion on the need for a more effective public administration based in solid governance principles, focused on the operational capacity of public administration and in the capacity of opening of the participation channels for the citizens to elaborate, follow up and assess public policies. In practice, they prioritize public policies affecting areas such as planning, budget, organizational structure, human resources, process management, governmental purchases, and information technologies (BARZELAY, 2001). According to Gaetani (2005), technically speaking, the use of technological innovations is an important factor for the modernization of public administration and e-gov can be understood as one of the most significant reforming initiatives of Brazilian public management.

The genesis of ICT use in Brazilian public administration lays in the initiatives by state ICT companies since the 1960s and state computing councils since the 1970s. Those two structures, albeit named differently back then, remain up to the present. Throughout the 1980s and 1990s, the states started adopting structures of computing planning and coordination. However, their initiatives were fragile, detached from the government's plans and public policies (CHAHIN and others, 2004). In the 2000s, some states and cities tried new public computing organization models and developed projects for the improvement in services provided for the citizen, using ICT and e-democracy, understood here as the use of ICT in amplifying the practice of democracy and in the management of public policies. Specifically in public policies of governmental management, Brazil faces great challenges, such as the labor relations in the ambit of public power; the definition of organizational architecture; the processes of budget planning and execution; the control mechanisms and the public expenses audit; and the rules for bidding and for hiring goods and services. In order to face these challenges, ICT has been used to support of people and competences management; to obtain information and indicators for making decisions; in the management of projects and goals; in the integration of planning systems; in the expenses follow-up; in the budget management; in the implementation of management information systems; and in systems allowing transparency of public expenses (GAETANI, 2005).

Brazilian academic literature, in the past decade, includes researches on various aspects of e-gov or electronic governance, such as Akutsu and Pinho (2002); Ruediger (2002); Ramos and Ramos (2003); Frey (2003); Fernandes (2007); Knight, Fernandes and Cunha (2007); Pinho (2008); Diniz and others (2009); Cunha and Pozzebon (2009). There are researches related with ICT strategies and management models for the public sector, implementation of information systems, follow-up and assessment of public policies, social projects and programs, and digital inclusion, in addition to reports on specific aspects such as e-services and e-commerce.

The technological development has allowed the growth in electronic services, the opening of communication channels with society, and the disclosure of public administration initiatives. Despite the advances in ICT and the studies on e-gov in the context of Brazil, we believe it is important to dwell on institutional arrangements of e-gov and ICT, as the use of information technologies does not bring about the same effects in all contexts.

\section{CONCEPTUAL MODEL - E-GOV POLICIES AND INSTITUTIONALISM}

A large part of the discussions and researches on e-gov and technology are based on an idea that the application of ICT and the organizational transformation keep cause and effect relations (AVGEROU, 2000). On this subject, Fountain (2005) highlights that, in such reports, ICT leads to a series or predictable changes and to greater organizational effectiveness. The idea that the initiatives of the agents are rational and maximize efficiency and efficacy is a commonly accepted assumption in researches on ICT (AVGEROU, 2000). Nevertheless, according to that author, such causality is not so simple to be observed and the studies on information technology need to focus on the institutional context where decisions are made. Thus, the neo-institutional analysis has the potential to help understand the means by which institutions influence the design, use and consequences of technology in organizations.

Therefore, we built a conceptual model anchored in neo-institutionalism of rational choice aiming to study e-gov policies of the states in the Brazilian federation.

Institutions can be understood as symbolic systems comprised of regulating, normative, and cultural/cognitive elements that produce stability and meaning in a given 
social context as it determines the rules of the game to be observed by a group of actors. They are comprised of rules and norms that establish behavioral patterns of the actors and manipulate a series of sanctions - rewards and punishments - aiming to influence the agents' behavior in a political game (HALL and TAYLOR, 1996; SCOTT, 2001).

Scott (2001) offers and interesting analytical cut to facilitate the use of institutional theory in organizational analysis. In his view, institutionalist studies can be divided in two foci: the first is based on regulating and normative aspects, following the rules of the game in an organizational context and enforcement mechanisms. It corresponds to the instrumental tradition of the new institutionalism represented by the economical lines and rational choice (HALL and TAYLOR, 1996). Theoreticians in this approach assume that individuals seek to know the rules of the political game so as to maximize their benefits and minimize their costs. In this case, institutions describe possible alternatives for the actors. They also provide enforcement mechanisms and information that reduce the uncertainty regarding the behaviors of others. The authors who adopt this approach assume that individuals seek to get to know the rules of the political game, from the permitted and forbidden movements to the penalties for those who infringe them, so as to maximize their payoffs.

Scott (2001) mentions another group of institutional studies based on a cultural/cognitive or sociological line. They emphasize the extent to which the interpretation the actors give for a situation determines their choice. The conception of the institutions in this line points towards informal norms, habits, symbols and conventions that structure and shape up individuals' behavior.

According to Immergut (2006), neo-institutionalist analysis shows that preferences and decisions are products of the institutions and help analyze the reasons that lead the actors from a given context to choose a certain definition of interests and not another equally plausible one. For Goodin (1996), the institutions bring about the existence of designs or arrangements that promote a group of results. He states that institutional designs can be understood as the creation of an active format that causes results in a given context.

As previously mentioned, this paper uses the approach of rational choice to study e-gov policies designs in the states of the Brazilian federation. Thus, we study e-gov policies in an institution responsible for providing regulating and normative elements that will foment the creation of an institutional design capable of producing a group of e-gov results (OFFE, 1996). We state, then, that in an institutionalized e-gov policy, social structures and mechanisms were created determining the arrangements of state e-gov and structuring ICT management. Therefore, it works as a strong government element guiding the actors' course of action. On the other hand, if it is fragile, it will be subdued by other institutions working on state governments.

Figure 1 presents a model we built to observe the institutional design of e-gov policies.

The arrangement is formed by the conjugation of the institutional context (1) and the technical one (2). According to Scott and Meyer (1991), these two should not exclude each other, as each one of them produces organizational responses based on rationality. To consider the institutional context is important for Brazilian e-gov, as governments are inserted in an environment strongly marked by both formal and informal laws, rules and norms. Since the 1990s, there have been important attempts of administrative reforms in Brazil with new management tools. On the other hand, e-gov depends on ICT technical advances, which is marked by innovations, both in management associated with technology and in the technological development itself, as can be noted in the recent use of the web 2.0 tools.

Returning to Figure 1, the conjunction of institutional (1) and technical (2) elements form the institutional design (3) of e-gov initiatives in Brazil. This design affects how technology is managed (4). The elements considered in the technology management part (4) were chosen from a view presented by Weill and Ross (2006) on ICT governance. The "technology management" component was described so as to observe: i) how states create governance systems to manage e-gov with the definition of roles, duties and responsibilities of various agencies that comprise the public administration structure; ii) how they manage and prioritize ICT budget, which is important, as institutions influence how resources are allocated, defining the "rules of the game" in this allocation (SCOTT and MEYER, 1991); iii) the data administration architecture corresponding to the mapping of databases, to standardization of data elements and data modeling in public administration; iv) the management of the ICT infrastructure; v) and the identification of the prioritization of the applications. E-gov initiatives demand the construction of applications used to provide services to the citizen. Institutionalized e-gov policies define patterns and procedures for the development of governmental applications, in addition to presenting software products as a result, allowing, for instance, an enhancement in the offer of governmental services.

A fundamental element in Figure 1 is the understand- 
ing of enforcement mechanisms generated by e-gov policies. An institution can only be considered as such from the moment when there are mechanisms to guarantee its imposition. The sanction character of an institution would only be unnecessary in an environment where rewards have such advantages that all parts would perform their pre-established roles. This is a rather unfeasible ideal condition. Apart from enforcement, we have also considered in the design what Goodin (1996) pointed as a defining feature of the institutionalization process: its stable and recurrent nature. Institutions can be defined as a process by which organizations and procedures obtain value and stability. Therefore, e-gov policies need to be legitimized (3) in order to affect ICT management and e-gov results.

Finally, one will find e-gov results (6), which comprehend e-services, information transparency, effectiveness of governmental initiatives, and participation of citizens in the elaboration, follow-up and assessment of public policies. They also need enforcement mechanisms to come to exist.

In the following section we will discuss the development of the study of e-gov policies institutionalization in state governments.

\section{METHODOLOGY}

Our research perspective was inspired in texts and researches by Walsham (1995), Pozzebon (2003) and Barbosa (2008). The epistemological position that guided this paper is interpretativist. It starts from the assumption that reality is socially construed by actors involved in it and, hence, it is impossible to completely separate facts from values, like in the positivist paradigm (WALSHAM, 1995). The research issue - the object of analysis in this paper - is in the category called descriptive character research. The research instruments or techniques that were used focused on a qualitative approach, since they seek to "describe, decode, translate and, on the other hand, to reach a conclusion regarding the meaning - not the frequency - of certain phenomena of the social world" (MAANEN, 1983). They are flexible and applied to small sample units. The central research approach is formed by the study of multiple cases.

E-gov policies were studied in the realm of Brazilian state governments, which is justified by its relevance in the federative scenario of Brazil and also because e-gov

Figure 1 - Conceptual model for the analysis of e-gov policies

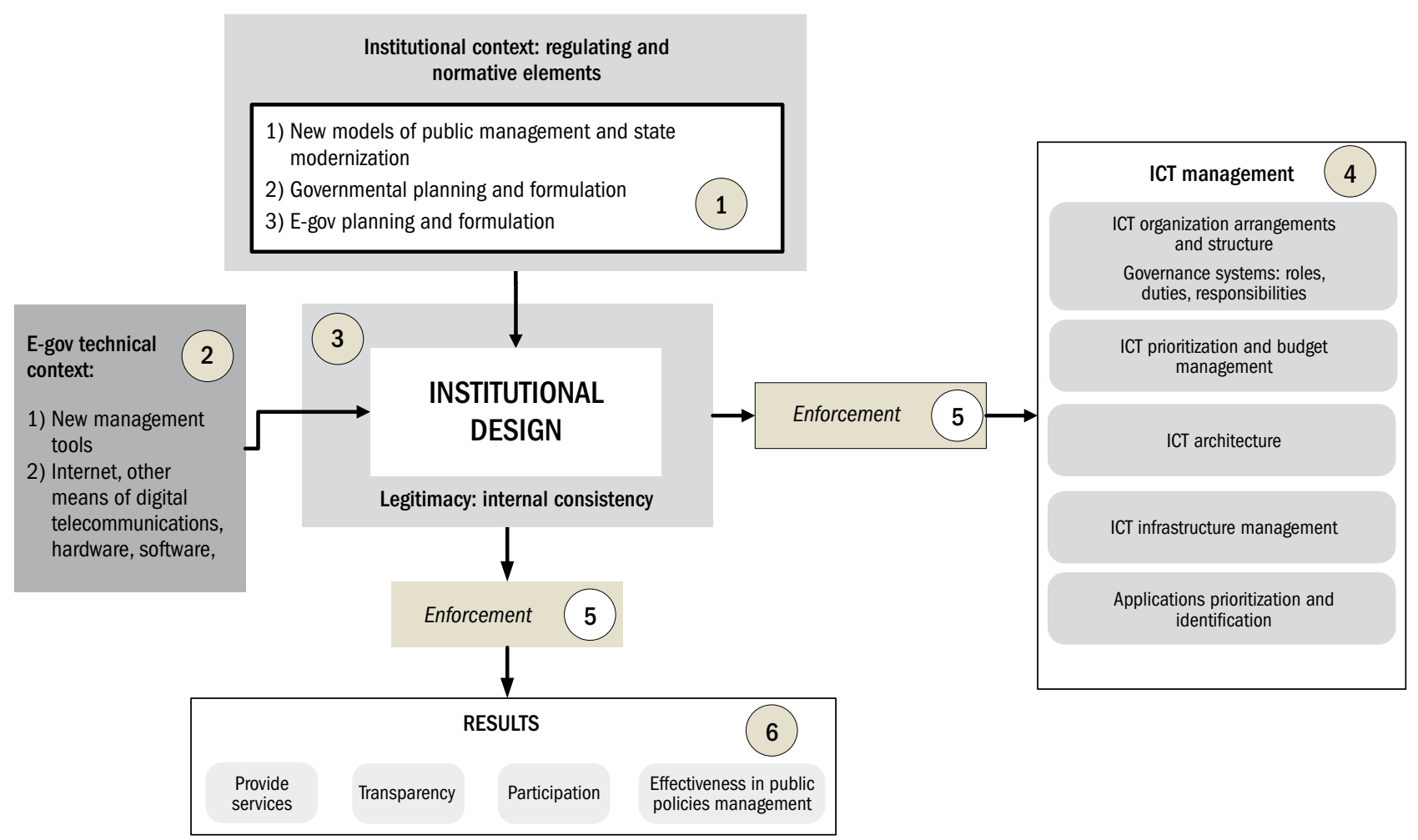


is still and agenda in process of assimilation in the policies of public state management (GAETANI, 2005; FERNANDES, 2007). The federation units chosen were the five states with the highest GDP in Brazil (IBGE, 2006): São Paulo, Rio de Janeiro, Minas Gerais, Rio Grande do Sul, and Paraná. Pernambuco also joined the group, as its e-gov policy has been an object of studies and is referenced as a good model of e-gov development (FUNDAP, 2006). The choice of six states was arbitrary and sought relevance in the studied cases. Although the state of Rio de Janeiro agreed to participate in our research, we were unable to get an interview booked.

From the conceptual model (Figure 1), we established the analysis categories. In the treatment of the data, the categorization strategy was important, as it allowed: (a) to group up elements, ideas and expressions around concepts able to synthesize the collection, analysis and interpretation of the data; (b) to translate the theoretical framework in analyzable items; and (c) to allow the construction of tools to collect data in a form coherent with the theoretical framework we adopted (MILES and HUBERMAN, 1994). The proposed categories were: ICT and e-gov legislation; ICT and egov policies planning, formulation and integration; ICT organizational structure and arrangements: governance systems, roles, duties, responsibilities; ICT prioritization and budget management; identification and prioritization of applications; infrastructure management; Information Technology architecture; enforcement. In addition to these, we created categories regarding "results" which were the services offered; transparency; participation; and effectiveness in public policies management. The categories can be seen in Exhibit 1:

The semi-structured interview script contemplated analytical categories displayed in Exhibit 1, consisting of 14 questions. At first, people chosen to answer it were: i) a high management state representative, secretary or undersecretary in coordination or planning areas; ii) the one responsible for e-gov state policies; iii) the president of the company or agency responsible for computing. After gathering the data, in December 2009,15 people had been interviewed in five states of the federation: 3 state secretaries, 2 state undersecretaries or joint secretaries, 4 state computing structure director-presidents (from the company or agency), 2 other computing structure directors, 4 people responsible for e-gov policies in the government. The interviews were recorded and transcribed.

The data analysis was made using the NVivo software and it followed the model by Miles and Huberman
(1994) in which the analysis is carried out in four phases: a) data collection; b) data reduction; c) data table or display; d) conclusion and checking. In the last phase, the researcher identifies regularities, patterns, explanations and flows of cause and effect.

To perform the reduction and the data table, we used a coding model creating free nodes, tree nodes and case nodes from the texts of the interviews (BARBOSA, 2008).

Each free node crated received a code: [99]-[yyyy][99]-[name of concept]. The first part [99] contained a question number from the script. The second [yyyy], an abbreviation of the analysis category; for instance, the code LEGINFO for ICT and e-gov legislation. The third part of the code [99] is the sequence of free nodes created in each category. The fourth part [name of concept] contained the name of the free node. This description allowed the researchers to quickly link the theoretical framework with the conceptual scheme displayed in Figure 1.

Once the free nodes were created, the data were reduced by means of creating tree nodes. They result from the hierarchical aggregation of the free nodes (figure 2). With them, it is possible to establish more comprehensive concepts, capable of facilitating the analysis. Based on the conceptual model, nine tree nodes were created: a) data architecture and administration; b) institutional context; c) governmental planning and formulation; d) e-gov policies institutionalization challenges; e) organizational arrangements and structure; f) IT management; g) ICT management history; h) e-services providing; i) information access and transparency.

Finally, case nodes were created aiming to express relations among the tree nodes (BARBOSA, 2008). They were named from the conceptual model and from the authors' experience in the subject of e-gov. There are three case nodes: 1) institutional context, formulation and governmental planning; 2) IT management; 3) results.

The case node (1) institutional context, formulation and governmental planning arose from the aggregation of tree nodes (b) institutional context; (c) formulation and governmental planning; (d) e-gov policies institutionalization challenges; (g) ICT management history. The case node (2) IT management was composed of tree nodes (a) data administration and architecture; (3) organizational structure and arrangements; (f) IT management. At last, the case node (2) results was composed of the aggregation of the nodes (h) e-services and (i) information access and transparency. 


\section{DATA ANALYSIS AND DISCUSSION}

From the first interactions with the material, 202 free nodes emerged from the interviews. They were reviewed, as there were duplicities and synonyms, resulting finally in 116 free nodes, made hierarchical in 9 tree nodes. After that, they were articulated into case nodes and used to organize the discussions in the following sections.

\section{Institutional context, formulation and governmental planning}

Exhibit 1 shows the first free nodes (12) organized in descending order of quantity of fragments from the interviews coded in each. In an interpretativist perspective, it is seemingly a contradiction to display the most frequent ones, as we aim to reach a concluding regarding meaning, not frequency, of certain phenomena of the social world (MAANEN, 1983). However, the meaning that emerged
Exhibit 1 - Analysis categories and foci

CONCEPTUAL MODEL
(FIGURE 1)
(1) Institutional context
(1) Institutional context

\section{ANALYSIS CATEGORIES}

Legislation of access

to e-gov governmental information

ICT and e-gov policies planning, formulation and integration

(4) Technology management and

(2) Technical context

(4) Technology management and

(2) Technical context

(4) Technology management and

(2) Technical context

(4) Technology management and

(2) Technical context

(4) Technology management and

(2) Technical context

(5) Enforcement

(6) Results

(6) Results

(6) Results
ICT organizational structure and arrangements: governance systems, roles, duties and responsibilities

ICT prioritization and budget management

Applications identification and prioritization

Infrastructure management

IT Architecture

\section{Enforcement}

Providing Services

Participation

Effectiveness in public policies management

\section{ANALYSIS FOCI}

E-gov aspects properly regulated;

E-gov aspects lacking regulation;

Regulation coverage.

Strategies and blockages to the development of ICT and e-gov policy;

Formalization of ICT and e-gov policy;

Horizontal coordination mechanisms among governmental units responsible for the implementation of ICT and e-gov programs;

Consensus in institutional logic? That is, do actors follow and join same patterns, norms and policies to run ICT initiatives?

Existing structures for the implementation of e-gov policies;

Governance models used for the implementation of e-gov policies;

Existing operational committees, workgroups etc;

Roles and responsibilities of the units responsible for planning ICT in state governments.

Decision-making rules existing in the ICT budget approval process;

How the existence/inexistence of normative and regulatory processes affect ICT investments.

Regulatory and normative processes governing the applications identification and prioritization process

ICT infrastructure management mechanisms

Existence of a model of data architecture;

Existence of data dictionary and syntax rules for corporative data;

Existence of organizational arrangements for architecture management.

Existing enforcement mechanisms

Maturity in providing services on the Internet

Participation mechanisms implemented on the Internet

Check answerers' perception on the contributions of ICT in the effectiveness of public policies. 
from various interactions with the empirical material confirm the frequency, making us comfortable to display it.

The first highlighted point is that state government ICT policies do not prioritize integrated planning, as there is no state view as a whole (line 1, Exhibit 1). ICT planning in state governments ends up blended in a series of sectored policies given the inexistence of e-gov policies formal planning (lines 2 and 3, Exhibit 1). Other elements reinforce the reality of a gap in e-gov planning and of the existence of uncoordinated initiatives, most noticeably: (a) the inexistence of e-gov policy formalization - including PPA (line 3, Exhibit 1); (b) Absence of ICT use institutionalization (line 10, Exhibit 1); and (c) ICT use based on the initiative of each secretarial or management sector (line 12).

For the interviewees there is no integrated view of ICT policies in those states. One of them states:

No, there is no central planning. I mean, then, there is no IT strategic planning. What's there are a few practices, good ones, not bad, but sporadic and performed by isolated individuals. A strategic IT guidance, for the state, for instance, what are all the great databases of the state? How can they be used? And so on. Throughout time, what works should be prioritized? This will be up to each department to propose to their system, their process, their project and to obtain this approval. (Interviewee \#15, interview data.)

Another one states:

(...) what is chosen as priority, is so done by a certain agency or department. It is not prioritized for the government or for the citizen, that is my view. If there's money left, great. all can be done. If there's no money left, each agency prioritizes itself. I think it's hard, but it has to be at least minimally done (...). As people themselves aren't committed to the state as a whole. They're more committed to their organization, the area they run. It's very hard to think state, very hard. (Interviewee \# 13, interview data, our underlining).

The fragmentation of e-gov initiatives appears repetitively in the speech of interviewees. Even not focusing on the

Figure 2 - Structure hierarchy of the nodes stored in QSR NVivo

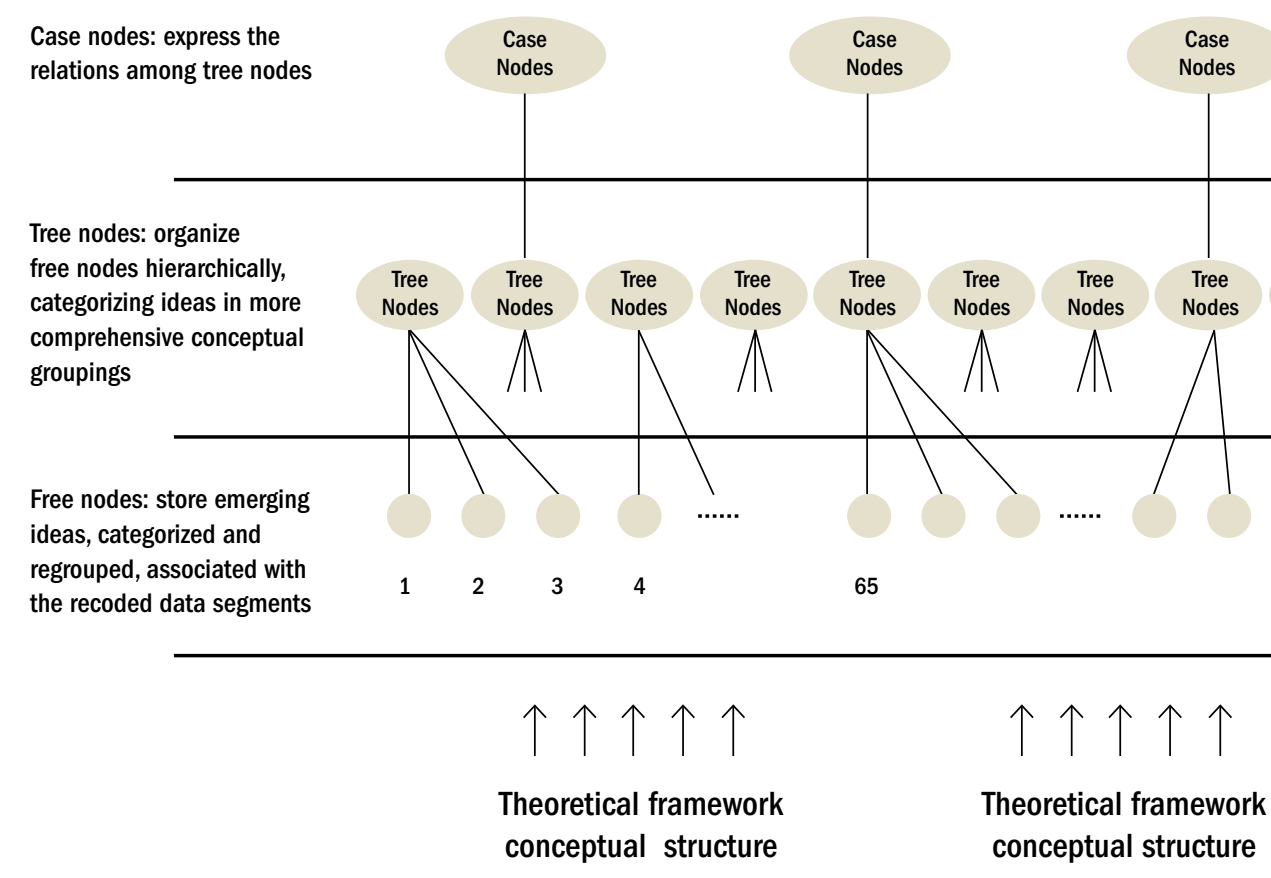

Source: Barbosa (2008), adapted by the authors. 
given number (71), the pattern emerges in the analysis.

E-gov projects, in a perspective of maturity, require the use of ICT to interlink the systems, processes, organizational units and organizations, network integration, generalized convergence among agencies responsible for providing services (FERNANDES, 2007; ONU/ASPA, 2008). Maturity is associated with the intensity with which e-gov projects and initiatives bring about public administration structure and processes transformation. As a result, it depends on the government's capacity of sustaining a transforming process, which relies on the alignment among strategies and public administration structures and e-gov program (FERNANDES, 2007). Furthermore, the discussion of advanced patters of public management relies on the assumption that there is a cooperation logic among agencies and entities, so that there's a more effective global effect in providing public service (ABRUCIO, 1997). Thus, the insularity of ICT policies shows an institutional pattern that does not generate enforcement conditions capable of promoting the integration of public state administration agencies and entities.

In most cases, an isolated normative view prevails institutionally in each organization or government area performing ICT implementations in a broader, yet disconnected way of technological policy, favoring cohesion in the use of ICT among governmental agencies. Integrating potencies tend to be neutralized by effective institutional arrangements, since the design in vigor favors the adoption of technology in a fragmented manner. There are no enforcement rules or mechanisms to run ICT initiatives harmoniously. It is a legitimate scenario for the actors to run ICT initiatives, since, although they highlight the need for integrated initiatives, there is nothing keeping e-gov initiatives to be run after an isolated fashion.

As indicated in line 3, Exhibit 1, there's no e-gov or ICT policy. The common mentioning is the inexistence of strong policies. There are initiatives running in an isolated manner, but with no coordination or organicity. So "the lack of policies leads to unfinished initiatives. It's just a collection of good intentions, isn't it?" (Interviewee $\# 11$ - fragment from the interview.) In addition, the mere existence of a written policy doesn't mean it is institutionalized and is no guarantee that e-gov coordinated initiatives will be created. According to North (1990), individuals act in a social context seeking to understand

Exhibit 2 - Partial presentation of the case node institutional context, formulation and governmental planning CASE NODE: INSTITUTIONAL CONTEXT, FORMULATION AND GOVERNMENT PLANNING

TREE NODES: INSTITUTIONAL CONTEXT; FORMULATION AND GOVERNMENT PLANNING; E-GOV POLICIES INSTITUTIONALIZATION CHALLENGES; ICT MANAGEMENT HISTORY

\section{FREE NODES}

06) PLANTIC - 01 - Inexistence of integrated planning and state view as a whole

2 06) PLANTIC - 03 - Existence of sector planning

3 06) PLANTIC - 04 - inexistence of e-gov policies formalization - including PPA

4 05) PLAN - 02 - Structuring programs with resource priorities

5

04) PLANTIC - 06 - E-gov evolution depends on changes on laws, decrees, structures (institutional changes). Alterations still inexpressive.

6 05) PLAN - 01 - Tools for formal strategic planning - PPA, PPAG, projects and plans

7 05) PLAN - 03 - Existence of strategic axes with the definition of initiatives and goals

8

06) PLANTIC - 09 - reactive ICT - does not meet demands, rebounds and has difficulties transforming business

9 06) PLANTIC - 08 - Transversal policies or structuring programs needing articulation and use of ICT

10 01) HIST - 05 - Absence of institutionalization and use of ICT

11 14) DES - 02 - Isomorphism - national and international patterns

12 04) EFET - 03 - Use of ICT based on the initiative of each secretarial or management sector
CODED

INTERVIEWS

13

13

9

8

7

8

7

5

5

4

6

6
11

10

CODED

FRAGMENTS

71

58

58

21

16

16

16

1

9

9

7 
the rules of the game so as to avoid forbidden movements and penalties. The aim is to maximize payoffs. The various agencies and entities adopt technology in a non-integrated manner and there are no constraints interposed between actors and the consecution of their preferences (HALL and TAYLOR, 2003). There is no cost, not even political, in the uncoordinated running of ICT initiatives.

The behavior of agencies and entities in ICT in state governments is an optimal response to the institutional context found. The tendency, therefore, is to give continuity to a scenario marked by fragmented initiatives, even if they present less-than-optimal collective results.

\section{IT management}

Regarding IT management, the nodes that emerged in the analysis point towards the difficulty of establishing criteria to guide the initiatives, indicated an incipient ICT management environment (Exhibit 3).

Notice that, in the chosen literature, ICT governance appears based on patterns that define mechanisms, formalizing relations and establishing rules and procedures to make sure that organizational aims are met (WEILL and ROSS, 2006). Exhibit 3 shows an environment of lack of formal processes to guide and direct the decisions regarding ICT, such as difficulties of establishing technical criteria for budget (line 5). Public administration agencies and entities have do not need to submit their technological initiatives to any sort of scrutiny and project selection to liberate resources. The aim of an investment approval process is associated with the capability of the investments in ICT to generate results towards the strategy of the organization (WEILL and ROSS, 2006) or, in the case of governments, their government plans. Lines 4, 7, 9 and 10 confirm the inexistence of methodologies for the management of projects, software requirements survey, ICT initiatives portfolio management and mapping, among others. This situation reveals that the institutional design in vigor is characterized by a low-standard governance technology.

States possess, at least, committees managing ICT (line 2, Exhibit 3), descending from Computing Committees created in the 1970s. Despite that, various interviewees state that they are not operational and aggregate little effectiveness to ICT management. It is small in its ability to bring about a framework to guarantee or help state executives to make decisions.

There is now in legislation an IT committee aiming to assess these demands, though, quite frankly, it's not working here, it's not operational. (Interviewee \#1, fragment from interview, our underlining.)

That, like COSITE, it doesn't work and never really worked. It worked badly in previous managements. As far as I know, it was never even instituted. (Interviewee \#11, fragment from interview, our underlining.)

The committees are little operational arrangements and they aggregate marginal effectiveness to ICT management. In addition to the lack of governance and the ineffectiveness of the committees, the other lines in Exhibit 3 reinforce the idea of fragility in ICT management in state governments.

It is important to highlight that the levels of maturity in ICT management among different departments in each state are different. The interviewees highlighted that there are agencies and departments with outstanding use of ICT such as the Treasury Department. One of the interviewees states:

The (...) State, by means of Professor (...) wanted to modernize the whole collection process, the whole budget control process, both internal and external, and obtained international resources. At the time, nearly 60 million US dollars were applied in the reformulation, reorganization and modernization of the Treasury. Then, there was a strong development. (Interviewee \#12, fragment from the Interview.)

Other participants point out differentiated ICT structures in state treasuries. Most states have Departments of Treasury with their own data centers and ample structures with a large quantity of professionals and ICT processes. Regarding the other departments, State Treasuries perform a leading role in governmental technological innovation due to a series of factors. Among them: 1) the convincing and consequent support of the high administration regarding the strategic need for IT in operations; 2) the existence of incentive programs to the modernization of the financial administration of Brazilian states and cities financed by development agencies that help keep or increase IT investments, such as, for instant, the national program of fiscal administration support (PNAFE), financed by the Inter-American Development Bank (IDB); 3) greater base of knowledge and professionals enabled to use ICT intensively; 4) a longer use of computational tools, consequently more mature, since state treasuries were historically one of the first groups in state governments to be computerized due to the need to control expenses and revenues. 
As the institutional context in vigor does not offer articulated patterns for technology management, nor does it interpose constraints for the actors to use e-gov coordinately, it is reasonable to infer that departments with higher degrees of development will continue to perform their investments and move away from those with incipient models.

Regarding the role of state computing organizations, the participants in this research mention they lack a clearer institutional mission:

There's no clear definition: "Why would I want an IT company in the State? Do I want it or not? Is it better to live with or without it? And if I do want it, I need to demand something from it." (Interviewee \#3, fragment from the interview, our underlining.)

This scenario is consistent with the observations made by Fernandes (2007). One of the major institutional design challenges in e-gov policies is to define, with clarity, the acting model for computing companies in Federal, State and City ambits. He states that there is no clear perception in Brazil on the proper role for computing organizations. For him, "the definition of their role in alignment with an e-gov strategy is one of the most important items in the institutionalization of Brazilian e-gov." (FERNANDES, 2007, p. 502).
Another important element refers to the architecture and administration of state government data. Advanced levels of e-gov involve cooperation structures in various agencies and a persistent work in order to guarantee the interoperability of the applications (HEEKS, 1998; ONU/ ASPA, 2008). The key to integrate processes, in a technological perspective, goes through effective management of the data of the organization.

Exhibit 4 shows partially the case node IT Management in the items specifically related with Data Administration.

One of the interviewees affirms:

There's none. That's what we're trying to set up now in this architecture. We're trying to make this integration happen, this data administration more effective. Not even more effective - make it happen, because it's just not there (Interviewee \#6, fragment from the interview.)

Data management is not completely absent, as there is management linked to each one of the systems, especially corporative ones that perform central functions such as budgets, finances, human resources, purchases, among others. Still, the management is vertical, restricted to the limit of each system and does not consider interconnections between processes. There are no patterns of interoperability. The capacity of ICT to offer quick and appropriate support to the reformulation of the processes and

Exhibit 3 - Partial presentation of the IT management case node

\section{CASE NODE: IT MANAGEMENT}

TREE NODES: DATA ARCHITECTURE AND ADMINISTRATION; ORGANIZATIONAL STRUCTURE AND ARRANGEMENTS; IT MANAGEMENT

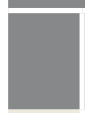

1

2

3

4

5

6

7

8

9 12) APLIC - 01 - Inexistence of process and forum to prioritize applications

10 06) PLANTIC - 10 - Inexistence of ICT initiatives portfolio management and mapping

\section{FREE NODES}

06) PLANTIC - 05 - Absence of governance - distance between intention and action

08) ARRJTIC - 01 - Little operative technology and management committees

09) ENFORCE - 02 - Absence of coercive conditions

09) ENFORCE - 01 - Fragility of the mechanisms to guarantee the implementation

10) ORÇTIC - 01 - Inexistence of technical criteria for IT corporative budget survey, excepting only certain departments such as SEF. needs
08) ARRJTIC - 05 - Inexistence of governance arrangements for the government as a whole

12) APLIC - 02 - Inexistence of mature methodologies of project management and requirements

10) ORÇIC - 04 - Sector budget governance - agencies determine autonomously their expense 
activities in public administration, without management and/or standardization of the data, can be compromised.

Therefore, the situation of technology management reinforces an e-gov development model characterized by a frail strategic direction, uncoordinated arrangements, and absence of established mechanisms in ICT. The institutional design does not offer enforcement conditions for the harmonious use of ICT.

State secretarial technology areas notice that the rules of the game are not constructed aiming to promote coordination and integration of e-gov initiatives. To act without integration offers a less expensive option, since there is not need to deal with typical difficulties of articulation among departments. And since there are no enforcement conditions (lines 3 and 4; Exhibit 3), an institutional design in which non-integrated decisions are legitimized is outlined (MMERGUT, 2006).

\section{Providing services, transparency and participation}

Now, the field of results. It is a fact that the use of ICT to provide public services has become part of the state governmental agenda. In the states, there are some leading agencies and entities in this initiative, such as the departments of treasury, traffic, education and commerce. Even when the services are not fully provided by digital means, we observed a concern in providing precise information to the citizens "if I am in the (...) state, regarding size, quantity of services the government provides for the citizen, to inform well is quite a precious service" (Interviewee \#14, fragment from interview).

There is growth in the ombudsman services provided. Some states establish criteria to make it possible to meet the demand for information and services directed to pub- lic administration. The presence of ombudsmen indicates that state governments moved towards paying satisfaction on the demands that are directed to them.

On the other hand, interviews design a scenario of services with low interactivity, problems in providing services when they involve more than one governmental agency and the need to modernize the back-office so as to facilitate the computerization of processes and services. Providing e-services is, in may cases, emergent and with little development in transversal services, limiting to each agency's initiatives.

The internet is used for the transparency of governmental information in the issues required by law. The use of e-gov initiaves for social participation is small. Advanced e-gov levels, called e-governance by authors such as Ruediger (2002), are still little developed.

At the moment when the research was carried out, there are citizen participation initiatives in public policies using digital means: "That's what they call democracy, isn't it? I still think it's rather inexpressive." (Interviewee \#13, fragment from the interview.)

Neither the integrated service providing nor the use of the internet as a mechanism of transparency and participation has reached it potential. These results corroborate those found in Pinho (2008), on Brazilian governmental portals with the appropriate technology, lower interactivity in services, absence of transparency excepting the items defined by law, and also the inexistence of participation mechanisms. The results show that the little integrated institutional arrangement of e-gov initiatives ends up damaging transversal digital services, to foment the ample exchange of information among public agencies and between them and society.

\section{Exhibit 4 - Partial presentation of the case node IT management}

\section{CASE NODE: IT MANAGEMENT}

TREE NODE: DATA ARCHITECTURE AND ADMINISTRATION; ORGANIZATIONAL STRUCTURE AND ARRANGEMENTS; IT MANAGEMENT

\section{FREE NODES}

11 11) ARQUIT - 01 - Little sharing and governance in data administration

11) ARQUIT - 02 - Inexistence of data administration - problem integrating citizen information

12 and for the government itself - each system regards citizens under different views

13

11) ARQUIT - 05 - Existence of data administration linked to systems with special attention to corporative systems

14 11) ARQUIT - 04 - Interoperability

15 11) ARQUIT - 07 - Establishing data administration would be too complex
CODED

INTERVIEWS

13

6

7

6

2
CODE

FRAGMENTS 


\section{CONCLUSION}

The aim moving this research was to understand the institutional design of e-gov in states of the Brazilian federation and how it facilitates the gains associated with e-gov. For such, we dwelled on the regulatory and normative context, the government planning formulation, e-gov and ICT, ICT management and the obtained results.

Brazilian e-gov appeared in the early 2000s in the context of State Reform movements, inheriting characteristics and utilization structure from ICTs in Brazilian public administration, with state computing organizations and committees similar to state computing councils. Some states and cities attempted certain changes and there was great availability of services to the population in the first decade of this century. New public management practices were and are being implemented in some Brazilian states, which require computing appropriateness. The Brazilian public sector is regulated, with formal financial and budget planning. The technological context is one of new technologies appearing and of new forms of using them, whose good example are the tools from Web 2.0 and social networks that use it.

Retarding computing and e-gov planning, there are no areas responsible for ICT management with the power to coordinate computing efforts. ICT budget is managed by each department (government area). In each state, there is also ICT budget managed by a structuring project. There is no budget coordination or articulation, which replicates efforts, rework, unnecessary costs, in addition to nearly insurmountable integration challenges. ICT architecture is almost inexistent, excepting certain corporative systems. Infrastructure management is fragmented throughout the agencies, although there are IT structures (companies or agencies) that could perform this role. There is no coordinated identification or prioritization of applications. The current concern focus is seemingly circumscribed to the form the organization should take (mixed-economy company, agency, autarchy) and not what role this organization should perform. There are flexibility and integration barriers that are hard to overcome if there is no concern with coordinated management and the establishment of standards for governmental data. IT management historical problems in the states, such as little alignment with governmental policies and with the needs of the departments, were not surmounted with the implementation of e-gov.

ICT policies in state government lack institutionalization. It is a challenge to establish solid guidelines for the initiatives in this area. E-gov is characterized by the fragmentation of initiatives and the difficulty in horizontal coordination among various governmental agencies. E-gov policies in state governments are not strong enough to interpose constraints to the behavior of the actors. Each agency plans by itself, not managing ICT from the standards fro the state and there is no corporative data administration. If, at a given moment, this design favored the offer of services to the population by the more computerized agencies and/or more entrepreneurs, such as the Department of Treasury and the Department of Traffic, now it interposes barriers to the offering of integrated and transactional processes in order to promote network integration.

The costs of "keeping it as it is" are smaller than those of facing the challenges of coordinating efforts. There are no enforcement mechanisms, nor financial ones, nor the loss of power or legitimacy, to make it disadvantageous for the actors to remain as they are. The results of e-gov policies are an offer of services that evolves within the scope of each department, but with great difficulties to offer integrated services, interdepartmental or even among different spheres of government or powers. There is no use of ICT in participation and transparency, excepting the areas defined by law (enforcement). The analysis on e-service providing, transparency and participation initiatives, and the effectiveness in public policies reveal that the current institutional design of state e-gov policies build barriers to its development. The institutional design limits the use of ICT, notably for not present regulating and normative elements capable of fomenting the implementation of e-gov focusing on the transformation of processes and the integration of initiatives in the various governmental agencies.

Regarding the agenda for the governments, we start from the observation that it is necessary to invest in e-gov, with no naive perceptions of a technological determinism, and understanding that state e-gov institutional arrangements, complex and with multiple actors, inherited historical characteristics from ICT use in Brazilian governments and from the governmental context. Firstly, it is necessary to build ICT policies that leverage government strategies. Secondly, e-gov guidelines need to interpose obligations to the actors and enforcement conditions for public managers. Still, e-gov initiatives seem to lack leadership and require strategy to replace discourses and broaden the public administration transformation that literature announces. Finally, the following items emerged in our research as important dimensions for formulation and planning: ICT resource management and their structures and arrangements; data architecture and administration, 
so as to reach results - providing public services, transparency, participation and effectiveness of public policies.

\section{REFERENCES}

ABRUCIO, F. L. O impacto do modelo gerencial na administração pública: um breve estudo sobre a experiência internacional recente. Cadernos Fundação Escola Nacional de Administração Pública, n. 10, 1997.

ABRUCIO, F. L. Reforma do Estado no Federalismo Brasileiro e a Articulação entre o Governo Federal e os Estados. O caso do Programa Nacional de Apoio à Modernização da Gestão e do Planejamento dos Estados. In: CONGRESO INTERNACIONAL DEL CLAD SOBRE LA REFORMA DEL ESTADO Y DE LA ADMINISTRACIÓN PÚBLICA, 9, Madrid, 05.11.2004.

AKUTSU, L; PINHO, J. A. G. Sociedade da informação, accountability e democracia delegativa: investigação em portais de governos no Brasil. Revista de Administração Pública, v. 36, n. 5, p. 723-745, 2002.

ARAÚJO, W. F. G. A avaliação de sítios governamentais como instrumento para melhoria dos serviços e informações on-line: da concepção aos resultados. In: MINAS GERAIS. Secretaria de Estado de Planejamento e Gestão. $1^{\circ}$ Premio Excelência em Gestão Público do Estado de Minas Gerais: coletânea dos trabalhos vencedores. Belo Horizonte: Secretaria de Estado de Planejamento e Gestão, 2006. p. 17-68.

AVGEROU, C. IT and organizational change: an institutionalist perspective. Information technology and people, v. 13, n. 4, p. 234-262, 2007.

BAHIENSE, G. C. Uso Estratégico de Tecnologia da Informação em Secretarias de Fazenda no Brasil. In: ENCONTRO NACIONAL DA ASSOCIAÇÃO DE PÓS-GRADUAÇÃO E PESQUISA EM ADMINISTRAÇÃO, 26, Salvador, 2002. Anais. Salvador: ANPAD: 2002.

BARBOSA, A. F. Governo eletrônico: dimensões da avaliação de desempenho na perspectiva do cidadão. Dissertação de Doutorado em Administração de Empresas, Escola de Administração de Empresas de São Paulo da Fundação Getulio Vargas, São Paulo, 2002.

BARBOSA, A; FARIA, F. I; PINTO, S. L. Governança eletrônica no setor público. In: KNIGHT, P. T.; FERNANDES, C. C. C.; CUNHA, M. A. (Orgs) E-desenvolvimento no Brasil e no mundo: subsídios e Programa E-Brasil. São Caetano do Sul: Yendis, 2007.

BARZELAY, M. The new public management: improving research and policy dialogue. Berkeley: University of California Press, 2001.

BRASIL, Presidência da República do. Plano Diretor da Reforma do Aparelho do Estado. Brasília: MARE, 1995.

BRESSER PEREIRA, L. C. Uma reforma gerencial da administração pública no Brasil. Revista do Serviço Público, v. 49, n. 1, p. 5-42, 1998.

CHAHIN, A; CUNHA, M. A; KNIGHT, P. T; PINTO, S. L. E-gov.br, a próxima revolução brasileira: eficiência, qualidade e democracia. O governo eletrônico no Brasil e no mundo. São Paulo: Prentice Hall, 2004.

CUNHA, M. A; POZZEBON, M. O uso das tecnologias da informação e comunicação para melhoria da participação na tomada de decisão pública. In: ENCONTRO NACIONAL DA ASSOCIAÇÃO DE PÓS-GRADUAÇÃO E PESQUISA EM ADMINISTRAÇÃO, 33, São Paulo, 2009. Anais. São Paulo: ANPAD: 2009.

DIMAGGIO, P. J; POWELL, W. W. Introduction. In: POWELL, W. W; DIMAGGIO, P. J. (Eds) The New Institutionalism in Organizational Analysis. University of Chicago Press, Chicago, 1991.

DINIZ, E; BARBOSA, A; JUNQUEIRA, A. R. B; PRADO, O. O governo eletrônico no Brasil: perspectiva histórica a partir de um modelo estruturado de análise. Revista Administração Pública, v. 43, n. 1, p. 23-48, 2009.

FERNANDES, C. C. C. Organização do governo eletrônico no Brasil: situação atual, problemas e propostas. In: KNIGHT, P. T; FERNANDES, C. C. C; CUNHA, M. A. (Orgs) E-Desenvolvimento no Brasil e no mundo: subsídios e programa E-Brasil. São Caetano do Sul: Yendis, 2007.

FOUNTAIN, J. E. Construindo um estado virtual. Tecnologia da informação e mudança institucional. Brasília: ENAP, 2005. 296 p.

FREY, K. Governança urbana e redes sociais: o potencial das novas tecnologias da informação e comunicação. In: ENCONTRO NACIONAL DA ASSOCIAÇÃO DE PÓS-GRADUAÇÃO E PESQUISA EM ADMINISTRAÇÃO, 27, Atibaia, 2003. Anais. Atibaia: ANPAD: 2003

FUNDAP. Seminário avanços e perspectivas da gestão pública nos estados: relatório do painel governo eletrônico. Fundação do Desenvolvimento Administrativo, São Paulo, 9 de março de 2006

GAETANI, F. Estratégia e Gestão da Mudança nas Políticas de Gestão Pública. In: LEVY, E; DRAGO, P. A. (Orgs) Gestão pública no Brasil contemporâneo. São Paulo: FUNDAP, 2005.

GOODIN, R. (Org) The Theory of Institutional Design. Cambridge: Cambridge University Press, 1996.

HALL, P. A; TAYLOR, R. C. R. As três versões do neo-institucionalismo. Lua Nova, n. 58, p. 192-223, 2003.

HALL, P. A; TAYLOR, R. C. R. Political science and the three new institutionalisms. Political Studies, 1996.

HEEKS, R. Information systems and public sector accountability. Manchester: Institute for Development Policy and Management. Information Systems for Public Sector Management -Working Paper Series, 1. 1998.

HOBSBAWM, E. Era dos extremos: o breve Século XX. São Paulo: Cia das Letras, 1995.

IBGE. INSTITUTO BRASILEIRO DE GEOGRAFIA E ESTATÍSTICA Contas Regionais do Brasil 2004. Boletim Contas Nacionais número 17. Rio de Janeiro, 2006.

IMMERGUT, E. O núcleo teórico do novo institucionalismo. In: SARAIVA, E; FERRAREZI, E. (Orgs) Políticas públicas. Brasília: ENAP, 2006. p. 155-196.

JEPPERSON, R. L. Institutions, institutional effects, and institutionalization. 
In: POWELL, W. W; DIMAGGIO, P. J. (Eds) The New Institutionalism in Organizational Analysis. Chicago: The University of Chicago Press, 1991. p. 143-163.

KNIGHT, P. T; FERnANDES, C. C. C; CUNHA, M. A. (Orgs) E-Desenvolvimento no Brasil e no mundo: subsídios e Programa E-Brasil. São Caetano do Sul: Yendis, 2007.

MAANEN, J. Reclaiming qualitative methods for organizational research: a preface. In: MAANEN, J. (Ed) Qualitative Methodology. Newbury Park: Sage, 1983.

MIGNERAT, M; RIVARD, S. Positioning the Institutional Perspective in Information Technology Research. Chaire de Gestions Stratégique des Technologies de L'Information, 2005.

MILES, M; HUBERMAN, A. An expanded sourcebook qualitative data analysis. Thousand Oaks: Sage, 1994.

MINTZBERG, H. Managing government, governing management. Harvard Business Review, v. 76, n. 3, p. 75-83, 1996.

NORTH, D. Institutions, institutional change and economic performance. Nova York: Cambridge University Press, 1990.

OFFE, C. Institutions in wast European transitions. In: GOODIN, R. (Org) The Theory of Institutional Design. Cambridge. Cambridge University Press, 1996.

ORGANIZAÇÃO DAS NAÇÕES UNIDAS. Benchmarking e-government: a global perspective. Nova York: UN/DPEPA, 2008.

PINHO, J. A. G. Investigando portais de governo eletrônico no Brasil: muita tecnologia, pouca democracia. Revista de Administração Pública, v. 42, n. 3, p. 471-493, 2008.

POZZEBON, M. The implementation of configurable technologies: negotiations between global principles and local contexts. 2003. 352 p. Tese de Doutorado, McGill University, Montreal, 2003.

RAMOS, R. E. B; RAMOS, A. S. M. As práticas internacionais de estratégia de governo eletrônico e inclusão digital e as perspectivas para estratégia de política pública no Brasil: os casos de Estados Unidos, Reino Unido e Canadá. In: ENCONTRO NACIONAL DA ASSOCIAÇÃO DE PÓSGRADUAÇÃO E PESQUISA EM ADMINISTRAÇÃO, 27, Atibaia, 2003. Anais. Atibaia: ANPAD, 2003.

RUEDIGER, M. A. Governo eletrônico ou governança eletrônica. Conceitos alternativos no uso das tecnologias da informação para o provimento de acesso cívico aos mecanismos de governo e da reforma do Estado. In: CONCURSO DE ENSAYOS E MONOGRAFÍAS DEL CLAD SOBRE REFORMA DEL ESTADO Y MODERNIZACIÓN DE LA ADMINISTRACIÓN PÚBLICA "GOBIERNO ELECTRÓNICO", 16, Caracas, 2002

SCOTT, W. R. Institutions and organizations. Thousand Oaks, CA: Sage, 2001

SCOTT, W. R; MEYER, J. W. The Organization of societal sectors: propositions and early evidence. In: POWELL, W. W; DIMAGGIO, P. J. (Eds) The New Institutionalism in Organizational Analysis. Chicago: The University of Chicago Press, 1991. p. 108-140.

WALSHAM, G. Interpretive case studies in IS research: nature e method. European Journal of Information Systems, v. 4, n. 2, p. 74-81, 1995

WEILL, P; ROSS, J. W. Governança de tecnologia da informação: como as empresas com melhor desempenho administram dos direitos decisórios de TI na busca por resultados superiores. São Paulo: Makron Books, 2006.

ZUCKER, L. G. The role of Institutionalization in Cultural Persistence. In: POWELL, W. W; DIMAGGIO, P. J. (Eds) The New Institutionalism in Organizational Analysis. Chicago: The University of Chicago Press, 1991. p. 83-107. 